\section{Survival of Ralstonia solanacearum Race 4 in Drainage Water and Soil and Detection with Immunodiagnostic and DNA-based Assays}

\author{
Mathews L. Paret ${ }^{1,3}$, Ryo Kubota ${ }^{2}$, Daniel M. Jenkins ${ }^{2}$, \\ and Anne M. Alvarez ${ }^{1,4}$
}

AdDitionAl INDEX wORDs. bacterial wilt, edible ginger, exopolysaccharide, Immunostrips ${ }^{\circledR}$

Summary. Ralstonia solanacearum (Rs) race 4 strains cause bacterial wilt of edible ginger (Zingiber officinale). The survival of the pathogen was studied in plant-free soil and potting medium in the presence of plants inoculated by different methods (non-wounded, rhizome-wounded, and stem-wounded) and irrigated on different schedules (alternate and daily). Detection thresholds for Rs were determined for an enzyme-linked immunoabsorbent assay (ELISA), immunostrip assay, and polymerase chain reaction (PCR) using drainage water from soil and potting medium containing known concentrations of Rs. In the absence of a plant or in the presence of non-wounded plants, Rs populations declined rapidly in drainage water from potting medium during the first 9 days and were undetectable after 81 days. When plants were stem- or rhizome-wounded, Rs populations increased by two to three orders of magnitude from the initial population levels for the first 9 to 19 days and then gradually declined and became undetectable after 89 days. Results were similar in experiments with soil except for non-wounded ginger plants, where the initial decline in Rs populations was followed by an abrupt increase after day 11 , reaching $7 \log \mathrm{cfu} / \mathrm{mL}$ on day 21 , then declining gradually to non-detectable levels after 137 days. The increase was attributed to natural infection of the plants followed by release of high populations of Rs into the irrigation water when plants wilted. When rhizome-inoculated plants were watered on alternate days, $\mathrm{Rs}$ was recovered from 97 to 129 days in soil and potting medium, but when the plants were watered daily, Rs was recovered in soil and potting medium up to 153 days after plant inoculation. ELISA using Psla monoclonal antibody detected the pathogen from $>95 \%$ of the samples from soil and potting medium when viable populations were $>5 \log \mathrm{cfu} / \mathrm{mL}$. The immunostrip assay (using the same antibody) detected the pathogen from $100 \%$ of the samples when viable populations were $>3 \log \mathrm{cfu} / \mathrm{mL}$. PCR based on the flagellin gene fliC detected the pathogen from $>95 \%$ of the samples from soil and from $>74 \%$ of the samples from potting medium when viable populations were $>4 \log \mathrm{cfu} / \mathrm{mL}$.

$\mathrm{E}$ dible ginger (Fig. 1A) is one of the most valuable and widely cultivated spice crops in the world (Ravindran and Babu, 2005). The global area under cultivation of

We gratefully acknowledge the support from U.S. Department of Agriculture. The work was partially funded by the Special Grants Program for Tropical and Subtropical Agricultural Research (Award 2004. 34135-15191), by ARS/Minor Crops Research (Award 59-5320-1-525), and by USDA-NRI Plant Biosecurity Award 2005-55605-16683

${ }^{1}$ Department of Plant and Environmental Protection Sciences, College of Tropical Agriculture and Human Resources, University of Hawaii at Manoa, 3190 Maile Way, St. John Plant Sciences Building 315, Honolulu, HI 96822

${ }^{2}$ Department of Molecular Biosciences and Bioengineering, College of Tropical Agriculture and Human Resources, University of Hawaii at Manoa, 1955 East-West Road, Agricultural Sciences Building 218, Honolulu, HI 96822

${ }^{3}$ Current address: North Florida Research and Education Center, University of Florida, 155 Research Road, Quincy, FL 32351.

${ }^{4}$ Corresponding author. E-mail: alvarez@hawaii.edu. edible ginger in 2008 was 426,998 ha with a harvested yield of 34,104 $\mathrm{kg} \cdot \mathrm{ha}^{-1}$ (Food and Agricultural Organization of the United Nations, 2010). One of the major production constraints of edible ginger is bacterial wilt disease (Fig. 1B) caused by Ralstonia solanacearum. Major crop losses due to the disease have been reported from almost all edible-ginger growing areas
(Hayward, 1994). The bacterium is known to cause severe wilting in many crops, including banana (Musa spp.), geranium (Geranium spp.), heliconia (Heliconia spp.), mulberry (Morus alba), peanut (Arachis hypogaea), plantain (Musa paradisiaca), potato (Solanum tuberosum), tobacco (Nicotiana tabacum), and tomato (Solanum lycopersicum) in the tropics, subtropics, and temperate regions (European Plant Protection Organization, 2004; Hayward, 1994; Kelman, 1953).

$R$. solanacearum is a soil-borne organism and is easily transmitted through field soil, runoff water, and infected planting material, and survives on weeds and latently infected potato, geranium, and edible ginger, as well as many other hosts (Janse et al., 2004; Pradhanang et al., 2000a; Shintaku et al., 2006). Previous studies have shown that high populations of Rs were released into drainage water when infected ginger plants were grown in potting medium (Paret et al., 2008a). However, no studies have reported survival of the ginger strains of Rs in field soil following different types of inoculation and under different irrigation schedules.

Enzyme-linked immunoabsorbent assay (ELISA), immunostrip assays (Immunostrips ${ }^{\circledR}$; Agdia, Elkhart, IN), polymerase chain reaction (PCR), and culturing are four methods widely used for detection and identification of Rs. ELISA and immunostrips use an Rs-specific monoclonal antibody $(\mathrm{MAb})$ that reacts with an exopolysaccharide (EPS) antigen (Alvarez, 2004; Alvarez et al., 1993; McGarvey et al., 1998). The PCR assay uses specific primers to amplify fliC fragments of Rs that are present in the ginger strains of Rs (Schonfeld et al., 2003). Detection limits for Rs with ELISA and PCR were reported as $>5 \log$ and $>2 \log$ $\mathrm{cfu} / \mathrm{mL}$, respectively (Alvarez, 2004; Horita et al., 2004). Immunostrips

\begin{tabular}{llll}
\hline $\begin{array}{l}\text { Units } \\
\text { To convert U.S. to SI, } \\
\text { multiply by }\end{array}$ & U.S. unit & SI unit & $\begin{array}{l}\text { To convert SI to U.S., } \\
\text { multiply by }\end{array}$ \\
\hline 0.4047 & $\mathrm{acre}(\mathrm{s})$ & $\mathrm{ha}$ & 2.4711 \\
29,574 & $\mathrm{fl} \mathrm{oz}$ & $\mu \mathrm{L}$ & $3.3814 \times 10^{-5}$ \\
29.5735 & $\mathrm{fl} \mathrm{oz}$ & $\mathrm{mL}$ & 0.0338 \\
1.1209 & $\mathrm{lb} / \mathrm{acre}$ & $\mathrm{kg} \cdot \mathrm{ha}^{-1}$ & 0.8922 \\
1 & $\mathrm{micron}$ & $\mu \mathrm{m}$ & 1 \\
28.3495 & $\mathrm{oz}$ & $\mathrm{g}$ & 0.0353 \\
0.001 & $\mathrm{ppm}$ & $\mathrm{g} \cdot \mathrm{L}^{-1}$ & 1000 \\
0.001 & $\mathrm{ppm}$ & $\mathrm{mL} \cdot \mathrm{L}^{-1}$ & 1000 \\
$\left({ }^{\circ} \mathrm{F}-32\right) \div 1.8$ & ${ }^{\circ} \mathrm{F}$ & ${ }^{\circ} \mathrm{C}$ & $\left(1.8 \times{ }^{\circ} \mathrm{C}\right)+32$
\end{tabular}


A.

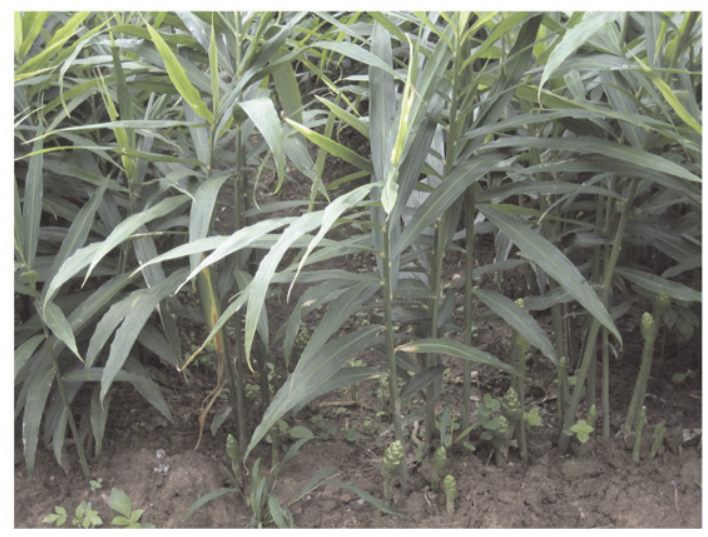

B.

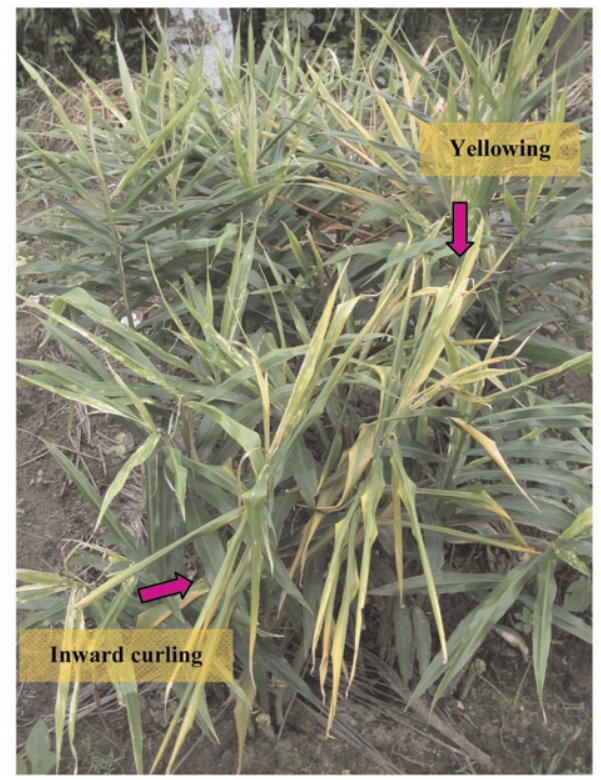

Fig. 1. (A) Healthy 5-month-old edible ginger plants in the field. (B) Yellowing and inward curling of leaves in edible ginger plants infected with the bacterial wilt pathogen, Ralstonia solanacearum race 4 . The symptoms are caused by plugging of the vascular tissues leading to blockage of water movement to upward parts of the stem and leaves.

were more sensitive than ELISA, with a detection limit of $>4 \log \mathrm{cfu} / \mathrm{mL}$ for pure cultures in water (Paret et al., 2008b). However, the strips have not been evaluated for detection of the bacterium in soil from ginger fields or in drainage water from soil and potting medium. Problems associated with direct analysis of environmental samples are many, and include low sensitivity, as in ELISA (Alvarez, 2004), possible inhibitors in PCR, and overgrowth of enterics during culturing (Pradhanang et al., 2000b). Inability to estimate soil-borne populations of Rs in ginger fields due to overgrowth of enterics like Enterobacter species in culture plates is a major constraint. Thus, soil treatments for bacterial wilt management are not initiated on time, leading to major crop losses.
The objectives of this work were to determine the survival of the Rs race 4 in soil without plants or with host plants inoculated by different methods and watered with different irrigation schedules, to determine population levels in drainage water from pots containing plants, and to evaluate immunodiagnostic and DNA-based techniques for direct detection of Rs from soil and water samples in comparison with culturing. The studies were carried out under controlled conditions in the greenhouse to determine the potential for disease spread through drainage water.

\section{Materials and methods}

BACTERIAL STRAIN. A wellcharacterized, representative strain of Rs race 4 (A4515) isolated from edible ginger in Hawaii was used for the experiment (Yu et al., 2003). This strain belongs to phylotype I (R. Kubota, unpublished data) based on the recently proposed classification scheme for Rs (Fegan and Prior, 2005). The Rs strain was streaked onto a modified tetrazolium chloride (TZC) medium (Norman and Alvarez, 1989) and was incubated for 48 to $72 \mathrm{~h}$ at $28^{\circ} \mathrm{C}$. Typical mucoid white colonies of Rs were transferred to sterile distilled water $\left(\mathrm{dH}_{2} \mathrm{O}\right)$, vortexed, and adjusted spectrophotometrically to $\mathrm{A}_{600 \mathrm{~nm}}=0.1$. Based on viable plate counts on TZC medium, this was equivalent to $10^{8}(8$ $\log$ ) cfu/mL (Paret et al., 2008a).

SURVIVAL OF RALSTONIA SOLANACEARUM IN FIELD SOIL AND POTTING MEDIUM. Two types of growth media were used for the experiments: soil (Hilo silty clay loam; $\mathrm{pH}=4.4$ ) was collected from a field not planted with ginger or any host crop of Rs at the Waikaea Research Station on the island of Hawaii, and a commercial potting medium $(\mathrm{pH}=$ 5.9, Sunshine Mix 4 Aggregate Plus; Sun Gro Horticulture Canada, Vancouver, BC, Canada) used by the ginger industry (Paret et al., 2008a). Bacterial wilt-free edible ginger rhizomes produced at the research station (Hepperly et al., 2004) were planted in pots containing one of the two substrates and irrigated with $200 \mathrm{~mL}$ of water daily for 5 months before the start of the experiments.

For Expt. I, media in 2-L pots were inoculated by three different methods designed to simulate different situations that could occur during cultivation as follows: 1) $25 \mathrm{~mL}$ of an aqueous suspension containing $8 \log$ $\mathrm{cfu} / \mathrm{mL}$ of Rs was poured into pots with no plants, 2) $25 \mathrm{~mL}$ of Rs was poured into pots containing ginger plants, and 3 ) the rhizome was wounded with a sterile scalpel before pouring $25 \mathrm{~mL}$ of the Rs onto the base of the plant. Three replicate pots were used for each treatment. An additional inoculation method was used for pathogenicity testing in the greenhouse: $1 \mathrm{~mL}$ of Rs inoculated into each stem (three stems inoculated per plant) with a sterile syringe. Pots were positioned over a petri plate and were irrigated with $200 \mathrm{~mL}$ of water on alternate days for $153 \mathrm{~d}$. Fifty milliliters of drainage water from the pots was collected subsequently on the petri plates and was vortexed. 
A $1-m L$ subsample was then taken to initiate a 10 -fold dilution series $(1 \times$ $10^{-1}$ to $1 \times 10^{-7}$ ) and $100 \mu \mathrm{L}$ of each dilution was plated onto a modified semiselective medium South Africa (SMSA) medium (Engelbrecht, 1994) to assess viable Rs populations. In addition to the assessment of bacterial populations in drainage water from soil and potting medium, the Rs populations in soil and potting medium were assessed directly by culturing once the populations in drainage water fell below $1 \log \mathrm{cfu} / \mathrm{mL}$. Pathogen survival was subsequently evaluated until growth no longer occurred on SMSA. A l-g sample (soil or potting medium) was vortexed for $10 \mathrm{~s}$ in $10 \mathrm{~mL}$ of $\mathrm{dH}_{2} \mathrm{O}$ and was allowed to settle. One milliliter of the supernatant was diluted and colonies were enumerated by the above methods. The presence of Rs in wilted plants was confirmed with Rsspecific Immunostrips as follows: a l-g plant tissue was excised from the collar region of the infected plant, surface sterilized with $0.6 \%$ sodium hypochlorite for $2 \mathrm{~min}$, rinsed with $\mathrm{dH}_{2} \mathrm{O}$ three times, and ground with a mortar and pestle in $1.0 \mathrm{~mL}$ of $\mathrm{dH}_{2} \mathrm{O}$. One hundred microliters of the extraction buffer BEBl buffer (Agdia) was mixed in a microcentrifuge tube with $100 \mu \mathrm{L}$ of the sample extract and tested with the Immunostrips. The experiment was repeated (Expt. II), and two pots were tested for each treatment.

In Expt. III, the plants were watered daily with $200 \mathrm{~mL}$ of water for $169 \mathrm{~d}$ and were tested with the methods to enumerate bacterial populations in drainage water, soil, and potting medium after inoculum was poured into pots containing rhizomewounded ginger plants. Three pots were tested per treatment. The samples from both the experiments were analyzed until the pathogen populations became non-culturable on modified SMSA medium. Non-inoculated plants served as controls in both experiments. The daily and alternate day irrigation schedules created soil moistures in the range $75 \%$ to $100 \%$ and $50 \%$ to $75 \%$, respectively, and are representative of two different scenarios that may occur in a field situation. The temperatures in the greenhouse were at a maximum of $32 \pm 4^{\circ} \mathrm{C}$ and a minimum of $18 \pm 2{ }^{\circ} \mathrm{C}$. The measurements were taken using Hygrochron $^{\circledR}$ (Maxim Integrated Products, Sunnyvale, CA).
Detection of RaLstonia SOLANACEARUM FROM DRAINAGE WATER by ELISA. The Psla antibody was used in ELISA to detect Rs in drainage water from soil and potting medium collected in Expt. III, and sensitivity of detection was evaluated for $145 \mathrm{~d}$ after inoculation. One hundred microliters of the drainage water was added into a $1.5-\mathrm{mL}$ tube and was centrifuged at $16,000 g_{n}$ for 3 min. The supernatant was discarded and the pellet was resuspended in phosphate-buffered saline (PBS [8.0 $\mathrm{g} \cdot \mathrm{L}^{-1}$ sodium chloride $(\mathrm{NaCl}), 1.15$ g. $\mathrm{L}^{-1}$ sodium phosphate $\left(\mathrm{Na}_{2} \mathrm{HPO}_{4}\right)$, $0.2 \mathrm{~g} \cdot \mathrm{L}^{-1}$ potassium phosphate $\left.\left(\mathrm{KH}_{2} \mathrm{PO}_{4}\right)\right]$ in $\mathrm{dH}_{2} \mathrm{O}$; pH 7.4$\}$ containing $0.5 \%\left(5 \mathrm{~mL} \cdot \mathrm{L}^{-1}\right)$ formalin and was incubated for $15 \mathrm{~min}$. The samples were washed three times with $0.85 \%\left(8.5 \mathrm{~g} \cdot \mathrm{L}^{-1}\right) \mathrm{NaCl}$ and resuspended in carbonate bicarbonate buffer $\left\{\right.$ CBC $\left[1.59 \mathrm{~g} \cdot \mathrm{L}^{-1}\right.$ sodium carbonate $\left(\mathrm{Na}_{2} \mathrm{CO}_{3}\right), 2.93 \mathrm{~g} \cdot \mathrm{L}^{-1}$ sodium bicarbonate $\left.\left(\mathrm{NaHCO}_{3}\right)\right]$ in $\mathrm{dH}_{2} \mathrm{O}$; $\mathrm{pH}$ 9.6\}. Samples $(100 \mu \mathrm{L})$ were pipetted into 96-well microtiter plates (three replications) and dried for $8 \mathrm{~h}$ in a circulating air incubator at $37^{\circ} \mathrm{C}$ before initiating the ELISA assay (Kaneshiro et al., 2008). Samples with plate readings greater than twice the standard deviation above the average negative control were considered positive (Kaneshiro et al., 2008). A total of 366 drainage water samples (183 each from Rs-infested soil and potting medium) were analyzed with ELISA, Immunostrips, and PCR.

Detection of RaLSTONia SOLANACEARUM FROM DRAINAGE WATER WITH IMMUNOSTRIPS. The sensitivity of Immunostrips was evaluated on drainage water samples for $145 \mathrm{~d}$. A $1-m L$ subsample from the drainage water was vortexed for $10 \mathrm{~s}$ and 100 $\mu \mathrm{L}$ of the sample was added to a 1.5$\mathrm{mL}$ microcentrifuge tube containing $100 \mu \mathrm{L}$ of BEBI buffer and was tested using the manufacturer's instructions.

Detection of RaLSTONIA SOLANACEARUM FROM DRAINAGE WATER BY PCR-FLIC. A PCR detection method that uses $f l i C$ primers targeting the gene coding for the flagella subunit of Rs (Schonfeld et al., 2003) was used for analyzing drainage water samples. Samples were filtered to enhance trapping of the cells and were washed to minimize the inhibitors (Kubota et al., 2008). One milliliter of the drainage water was trapped on a $0.2-\mu \mathrm{m}$ filter unit (Ultra-free MC GV column; Millipore, Billerica, MA) following centrifugation at $1000 g_{\mathrm{n}}$ for $2 \mathrm{~min}$. The filter was then washed with $1.5 \mathrm{~mL}$ of $\mathrm{l} \times$ TE buffer $[10 \mathrm{~mm}$ Tris, $\mathrm{pH} 7.5$; 1 $\mathrm{mm}$ ethylene diamine tetra acetic acid (EDTA), $\mathrm{pH}$ 8.0] and the unit was centrifuged at $1000 g_{\mathrm{n}}$ for $2 \mathrm{~min}$. The column was then crushed with a pair of pliers and the membrane was removed with sterile forceps and vortexed in $50 \mu \mathrm{L}$ of $1 \times$ TE buffer. The sample was incubated at $95{ }^{\circ} \mathrm{C}$ for $5 \mathrm{~min}$ followed by centrifugation at $2400 g_{\mathrm{n}}$ for $1 \mathrm{~min}$. Five microliters of the sample was used for PCR-fliC reaction.

PCR reactions were performed in $20-\mu \mathrm{L}$ reaction mixtures with $1 \mu \mathrm{L}$ of $1 \mu \mathrm{M} f l i C$-forward primer, $1 \mu \mathrm{L}$ of $1 \mu \mathrm{M} f l i C$-backward primer, $4 \mu \mathrm{L}$ of $5 \times$ Go Tag reaction buffer (Promega, Madison, WI), $0.16 \mu \mathrm{L}$ of $25 \mathrm{~mm}$ deoxynucleoside triphosphate (dNTP), $0.14 \mu \mathrm{L}$ of Taq DNA polymerase (5U), $8.7 \mu \mathrm{L}$ of double distilled water $\left(\mathrm{ddH}_{2} \mathrm{O}\right)$, and $5 \mu \mathrm{L}$ of template DNA. The PCR reaction was carried out as per the protocol described by Schonfeld et al. (2003). The amplified products were electrophoresed at $80 \mathrm{~V}$ for $40 \mathrm{~min}$ through a $2 \%$ agarose gel $(1 \times$ Tris-acetate-EDTA) and were stained with ethidium bromide. Appropriate size markers (Hyper ladder II; Bioline USA, Randolph, MA) were used for final confirmation of the amplified fliC DNA sequence.

Statistical analysis. The greenhouse experiments were set up in a randomized complete block design. Days for wilting and survival of the pathogen in soil and potting medium were statistically analyzed using analysis of variance, and the means were compared using Student-NewmanKeuls test (SNK, $P \leq 0.05$ ). The analysis was performed with SAS (version 9.2; SAS Institute, Cary, NC).

\section{Results and discussion}

SURVIVAL OF RALSTONIA SOLANACEARUM IN SOIL AND POTTING MEDIUM. All wounded plants in all the treatments wilted within $12 \mathrm{~d}$ in alternate days of the irrigation schedule (Expts. I and II, Table I) and in the daily irrigation schedule (Expt. III, data not shown). Non-wounded plants in soil took significantly longer (19.5-23 d) to wilt than wounded plants (Expts. I and II). The presence 
Table 1. Disease development in edible ginger, following inoculation of Ralstonia solanacearum (Rs) race 4 strain A4515 into the stem or rhizome of 5-month-old plants and maintained under alternate days irrigation schedule.

\begin{tabular}{|c|c|c|c|}
\hline \multirow[b]{2}{*}{ Growth medium } & \multirow[b]{2}{*}{ Inoculation methods } & \multicolumn{2}{|c|}{ Time to wilting $(\mathrm{d})$} \\
\hline & & Expt. I ${ }^{\mathrm{z}}$ & Expt. $\mathrm{II}^{\mathrm{z}}$ \\
\hline \multirow[t]{3}{*}{ Soil } & Ginger: non-wounded ${ }^{y}$ & $23.0^{\mathrm{u}}$ & $19.5^{\mathrm{u}}$ \\
\hline & Ginger: rhizome wounded ${ }^{x}$ & 7.3 & 9.0 \\
\hline & Ginger: stem wounded ${ }^{\mathrm{w}}$ & 8.7 & 8.5 \\
\hline \multirow[t]{3}{*}{ Potting medium } & Ginger: non-wounded & $\mathrm{NW}^{\mathrm{v}}$ & NW \\
\hline & Ginger: rhizome wounded & 7.7 & 8.5 \\
\hline & Ginger: stem wounded & 7.7 & 9.5 \\
\hline
\end{tabular}

${ }^{2}$ Expt. I had three pots per treatment; Expt. II had two pots per treatment.

y $20 \mathrm{~mL}(0.6763 \mathrm{fl} \mathrm{oz})$ of Rs $(8 \log \mathrm{cfu} / \mathrm{mL})$ were poured into the growth medium (soil/potting medium) with no wound to ginger plants and the rhizome; $1 \mathrm{cfu} / \mathrm{mL}=29.5735 \mathrm{cfu} / \mathrm{fl} \mathrm{oz}$.

${ }^{x} 20 \mathrm{~mL}$ of $\mathrm{Rs}(8 \mathrm{log} \mathrm{cfu} / \mathrm{mL}$ ) were poured into the growth medium (soil/potting medium) after wounding the rhizome by a sterile scalpel.

${ }^{w} 1 \mathrm{~mL}(0.0338 \mathrm{fl} \mathrm{oz})$ of $\mathrm{Rs}(8 \mathrm{log} \mathrm{cfu} / \mathrm{mL})$ were inoculated into the stem of ginger plants with a sterile needle. ${ }^{\mathrm{N} W}=$ no wilting (plants did not wilt until 153 and $129 \mathrm{~d}$ after inoculation for Expts. I and II, respectively).

"Column means are significantly different at $(P \leq 0.05)$, based on Student-Newman-Keuls test.

of Rs in wilted plants was confirmed with Immunostrips, and the bacteria were cultured on modified SMSA medium. The plants in the potting medium with no wounds showed no bacterial wilt symptoms until the end of the experiments. Immunostrips tested negative and the pathogen was not cultured from these plant samples. The initial population of Rs in drainage water ranged from 3 to $5 \log$ cfu/ $\mathrm{mL}$ (Fig. 2, A-C) in all treatments except one (Fig. 2D, stem-wounded ginger plants in soil), where there was no recovery until $3 \mathrm{~d}$, but the population increased to $5 \log \mathrm{cfu} / \mathrm{mL}$ within $9 \mathrm{~d}$. When plants were watered on alternate days (Expt. I), Rs was recovered up to $73 \mathrm{~d}$ from drainage water from all treatments (Fig. 2). There were no differences in recovery from pots with soil or potting medium in any treatments except two (Fig. 2B, non-wounded ginger plants in soil; Fig. 2D, discussed earlier). In the first case, the pathogen population increased abruptly after $11 \mathrm{~d}$ and continued to increase until $21 \mathrm{~d}$ when plants wilted. Populations then declined, gradually dropping to an undetectable level at $145 \mathrm{~d}$. Rs was undetectable at only one other point $(73 \mathrm{~d})$. In the rhizome-wounded treatments, Rs was recovered from drainage water for 89 to $105 \mathrm{~d}$ (Fig. 2C), and for $89 \mathrm{~d}$ for ginger-stem wounded treatments (Fig. 2D). In each of the treatments, the highest population of Rs recovered in drainage water coincided with the wilting stage of the plant (Table 1, Fig. 2).

The days for survival of $R s$ in various treatments in Expt. II showed a similar trend as in Expt. I (Table 1,
Figs. 2 and 3). However, the survival was for a shorter duration in all the treatments except plants in the stemwounded treatments in Expt. II. Rs was recovered in drainage water up to $121 \mathrm{~d}$ when plants were rhizomewounded and irrigated daily (Expt. III), but only to $105 \mathrm{~d}$ in the alternate day irrigation schedule (Figs. 2-4). In soil also, Rs survived longer following a daily irrigation schedule (153 d; data not shown) than when plants were irrigated on alternate days $(129 \mathrm{~d}$, Table 2). No significant differences in Rs population levels were noted between treatments for any of the time points of analysis in Expt. I (105-153 d) and Expt. II (81-129 d), except for the Rs population in non-wounded treatment at $121 \mathrm{~d}$ in Expt. I, which showed significantly higher levels compared with other treatments. There were no significant differences in survival of Rs populations in soil and potting medium in Expt. III at any of the time points of analysis (113$176 \mathrm{~d}$, data not shown).

The main sampling procedure used in the experiments was collection of drainage water from soil or potting medium followed by assessing Rs populations $(\mathrm{cfu} / \mathrm{mL})$. This was a non-destructive method of analysis and avoided injury to the tested plants. Wilting of the plants was thus due of the entry of Rs into the plant through the wounds created by the inoculation procedure in the experiment, and not due to the sampling procedure. However, because it also was important to know how long the pathogen survived in soil and potting medium $(\mathrm{cfu} / \mathrm{g})$, they were sampled directly after Rs populations fell below $\log \mathrm{l} \mathrm{cfu} / \mathrm{mL}$ in drainage water. The bacterium was recovered at later sampling times directly from soil/ potting medium and not from the drainage water from these pots (Table 2, Figs. 2-3).

The edible ginger cropping period ranges from 8 to 10 months and there is a 2 - to 4 -month period between harvest and new plantings. Rs can be introduced into a fallowed field through irrigation water and may infect healthy unwounded edible ginger plants as well as ginger rhizomes injured by farm implements or nematodes. The study indicates that the Rs race 4 can survive for 3 to 5 months in soil under these different conditions, and can be released into drainage water, whether a plant is present or not. This study confirms that the pathogen is constantly released from infected plants, corroborating previous studies on survival and the spread of Rs race 3 strains infecting potato (Alvarez et al., 2008; Caruso et al., 2005). This study also shows that delayed appearance of wilting symptoms is associated with later release and longer survival of the pathogen in drainage water. This is of particular importance, as infection at a later stage of growth could be more damaging to the new edible ginger plantings in the subsequent season. The potting medium currently used to propagate ginger suppressed Rs population levels in the absence of a plant wound, and this indicates its potential value for managing diseases.

Detection OF RALSTONIA SOLANACEARUM IN DRAINAGE WATER вY ELISA. ELISA indicated positive results on all samples with Rs viable populations $>7 \mathrm{log} \mathrm{cfu} / \mathrm{mL}$ (Fig. 4 , A and $\mathrm{B}$ ). ELISA detected Rs in $97.4 \%$, $97.1 \%, 79.3 \%, 52.4 \%, 16.7 \%$, and $5 \%$ of the samples from soil, and $100 \%$, $95.7 \%, 87.2 \%, 76.5 \%, 48 \%$, and $22 \%$ of the samples from potting medium when populations were between 6 and $7 \log , 5$ and $6 \log , 4$ and $5 \log$, 3 and $4 \log , 2$ and $3 \log$, and 1 and 2 $\log \mathrm{cfu} / \mathrm{mL}$, respectively. The assay did not show any positive results below viable Rs populations of $1 \mathrm{log}$ $\mathrm{cfu} / \mathrm{mL}$. All of the samples in the control pots with no Rs inoculum tested negative. During the prewilting period of the edible ginger plants $(0-10 \mathrm{~d})$, Rs detection with ELISA was variable and the sensitivity ranged 

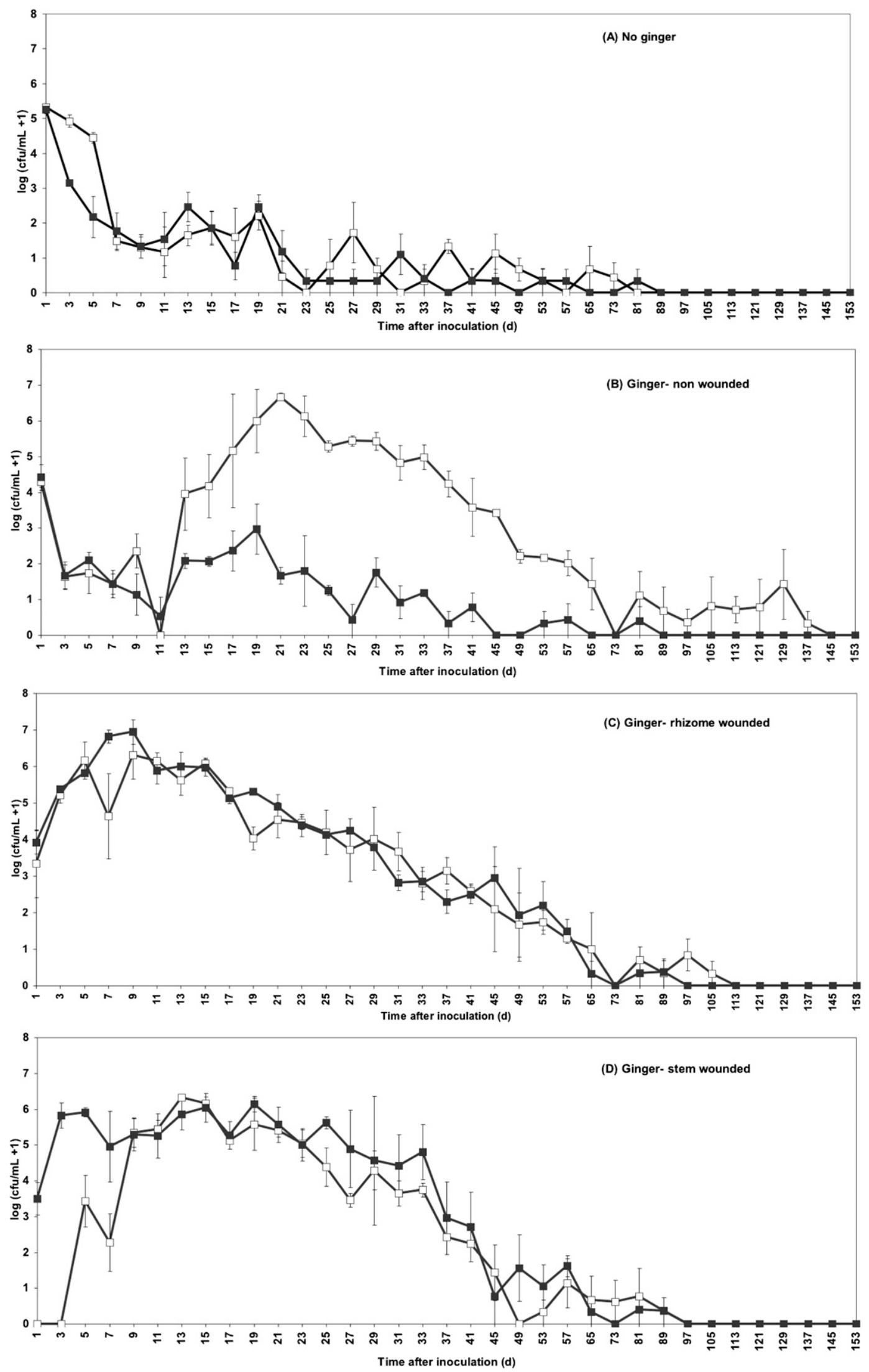

Fig. 2. Population of Ralstonia solanacearum race 4 strain A4515 in drainage water from soil ( $\square$ ) and potting medium ( $(\square)$ with or without ginger, inoculated by various methods and irrigated on alternate days (Expt. I): (A) no ginger, (B) ginger: non-wounded, (C) ginger: rhizome wounded, and (D) ginger: stem wounded. Viable cells are reported as log cfu per milliliter $(1 \mathrm{cfu} / \mathrm{mL}=$ $29.5735 \mathrm{cfu} / \mathrm{fl} \mathrm{oz}$ ). Each data point is the average of three samples and the errors bar represent sE. 

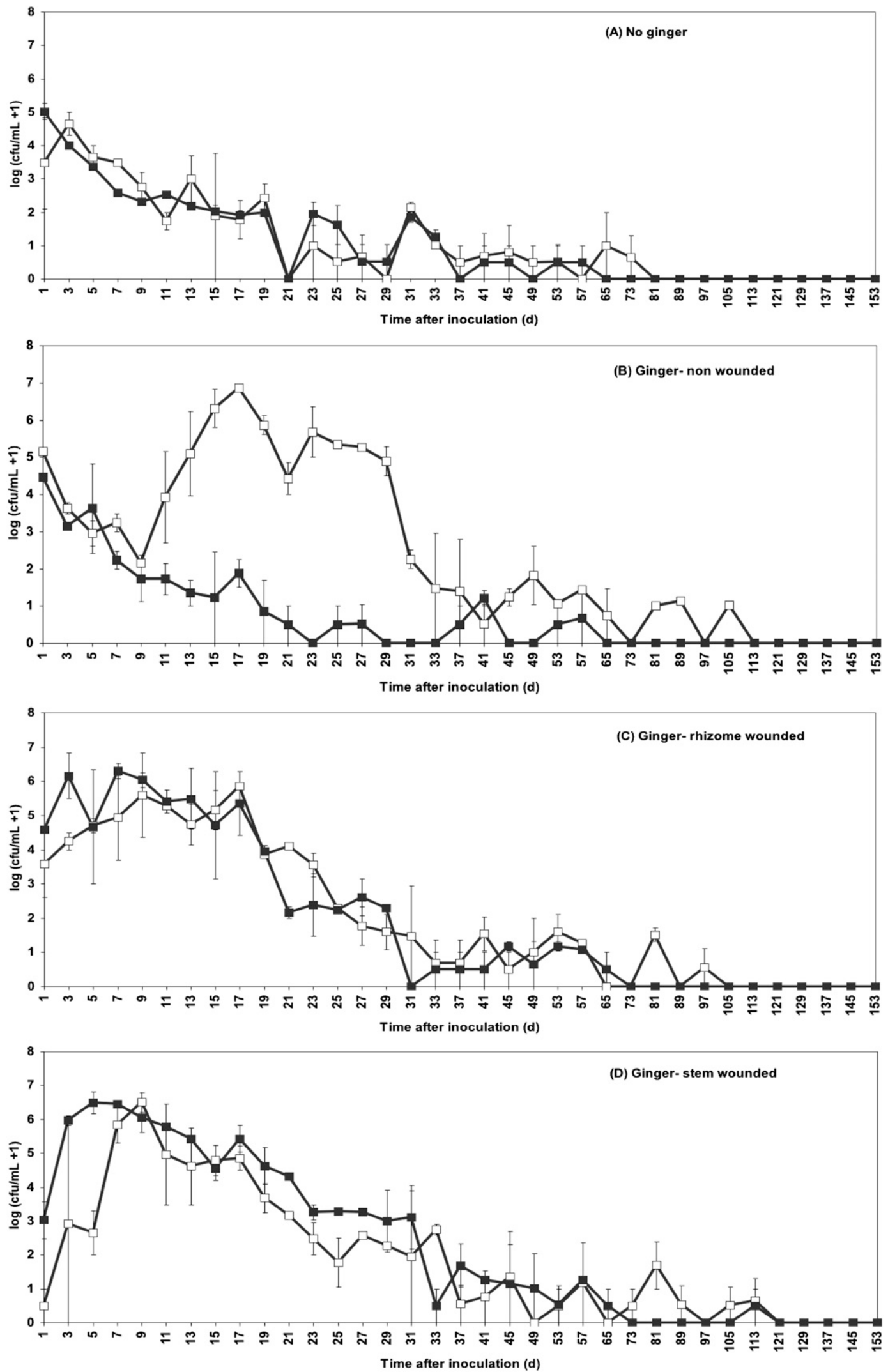

Fig. 3. Population of Ralstonia solanacearum race 4 strain A4515 in drainage water from soil ( $\square$ ) and potting medium ( $\square$ ) with or without ginger, inoculated by various methods and irrigated on alternate days (Expt. II): (A) no ginger, (B) ginger: nonwounded, (C) ginger: rhizome wounded, and (D) ginger: stem wounded. Viable cells are reported as log cfu per milliliter $(1 \mathrm{cfu} / \mathrm{mL}=29.5735 \mathrm{cfu} / \mathrm{fl} \mathrm{oz})$. Each data point is the average of two samples and the errors bar represent SE. 

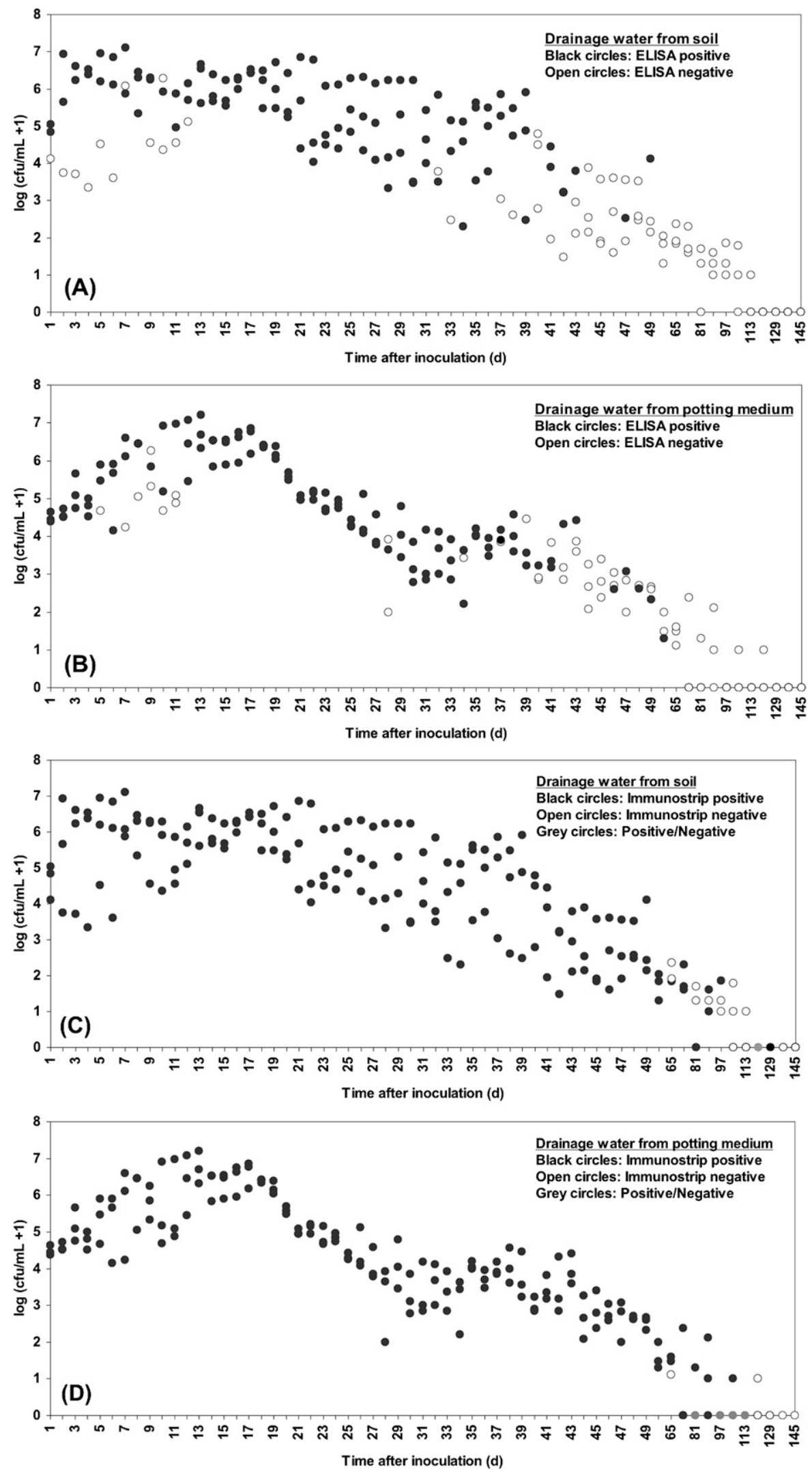

Fig. 4. Evaluation of sensitivity of detection of Ralstonia solanacearum race 4 strain A4515 in drainage water from pots with infested soil and potting medium and irrigated daily (Expt. III). Plate counts on modified SMSA (semiselective medium South Africa) were compared with ELISA using Psla monoclonal antibody (A and B); Immunostrips ${ }^{\circledR}$ (Agdia, Elkhart, IN) using Psla monoclonal antibody $(\mathrm{C}$ and $\mathrm{D})$; and polymerase chain reaction (PCR) using fliC primer (E and F). Black Circles ( $\bullet$ ) represent positive results, open circles $(\bigcirc)$ represent negative results, and grey circles $(\bullet)$ represent overlapping positive and negative samples. Viable cells are reported as $\log$ cfu per milliliter $(1 \mathrm{cfu} / \mathrm{mL}=29.5735 \mathrm{cfu} / \mathrm{fl} \mathrm{oz})$. 

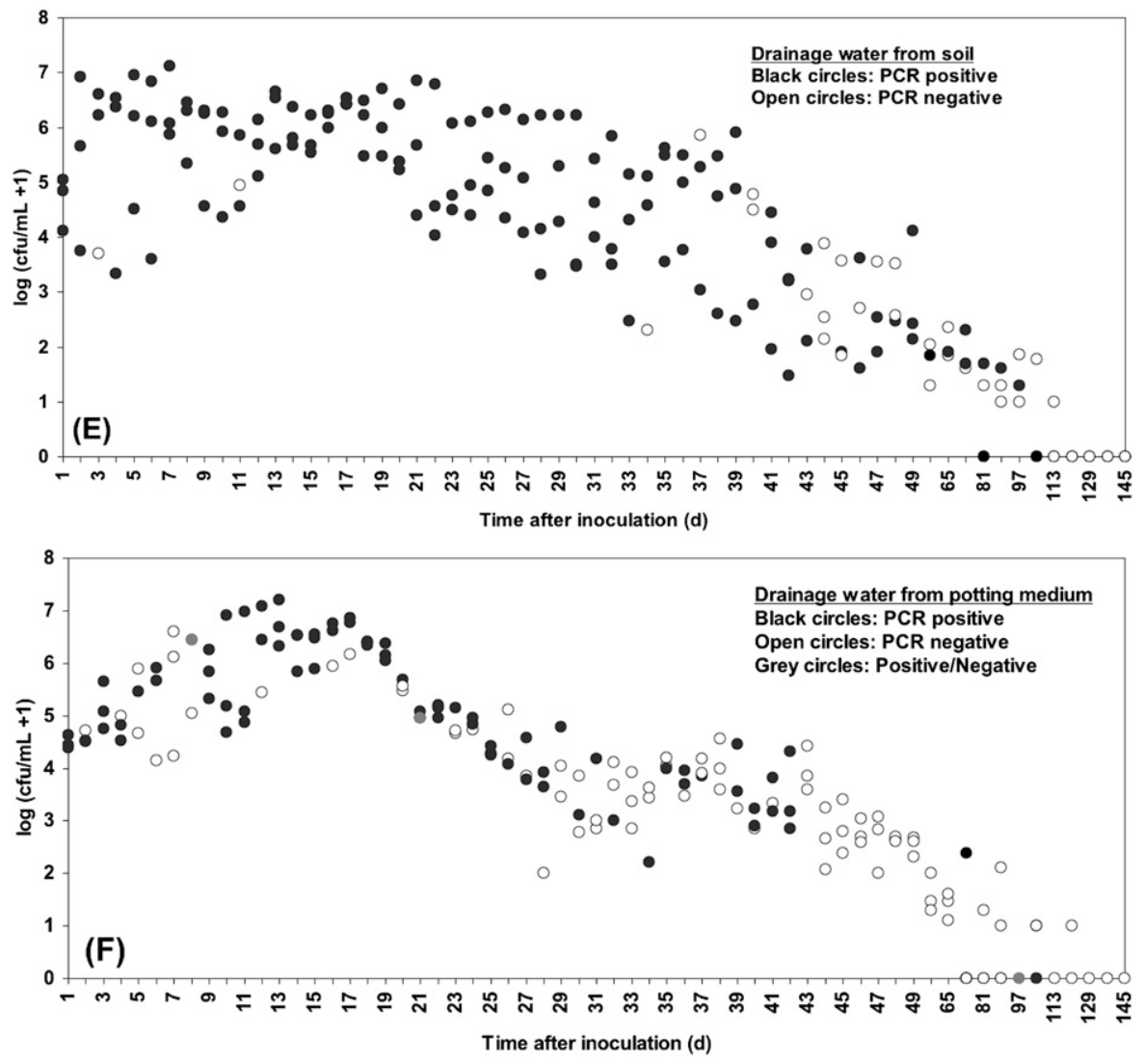

Fig. 4. (continued)

between 5 and $7 \log \mathrm{cfu} / \mathrm{mL}$ (Fig. 4, $\mathrm{A}$ and $\mathrm{B})$. The most consistent detection was during the post-wilting period (10-36 d). However, the pathogen was only detected a few times beyond $36 \mathrm{~d}$. All of the samples from the control pots with no Rs inoculum tested negative. ELISA performed comparatively well on samples from potting medium compared with those from the soil.

ELISA is a traditional method for detecting Rs and other bacterial pathogens, but sensitivity usually is not more than 5 to $6 \log \mathrm{cfu} / \mathrm{mL}$ (Alvarez, $2004)$. This is clearly validated in our study with $>95 \%$ detection when Rs populations were $>5 \log \mathrm{cfu} / \mathrm{mL}$ in drainage water from soil and potting medium. However, the detection was inconsistent when $\mathrm{Rs}$ populations were $<5 \log \mathrm{cfu} / \mathrm{mL}$. This was attributed to the numerous washing steps in the protocol, leading to loss of cells from microtiter plates, which compromised sensitivity.

Detection OF RALSTONIA SOLANACEARUM IN DRAINAGE WATER WITH IMMUNOSTRIPS. This assay detected Rs from 100\% of the samples when the populations were $>3 \log$ cfu $/ \mathrm{mL}$ (Fig. 4, C and D). No significant differences between soil and potting medium were observed for the Immunostrip detection assay, and $94.4 \%, 75 \%$, and $45 \%$ of the samples from soil, and $100 \%, 88.9 \%$, and $40.7 \%$ of the samples from potting medium tested positive when populations were between 2 and $3 \mathrm{log}, 1$ and $2 \log$, and 0 and $1 \log \mathrm{cfu} / \mathrm{mL}$, respectively. The detection was consistent during early wilting $(0-10 \mathrm{~d})$ and at severe wilting (10-15 d) stage. During the post-wilting (beyond 15 d), the assay consistently gave positive results up to $54 \mathrm{~d}$. Positive results using Immunostrips were observed on samples collected as late as $129 \mathrm{~d}$. None of the samples from the control pots (no Rs inoculum) tested positive. Immunostrips were more sensitive than ELISA in detecting Rs from drainage water (Fig. 4, A-D).

The role of EPSI as a virulence factor in Rs, and its ability to enhance symptom expression following root infection and vascular colonization of tomato plants, has been previously demonstrated (Araud-Razou et al.,
1998; Denny and Baek, 1991). Also, EPSI is produced abundantly by Rs in culture media and in planta (Orgambide et al., 1991). The most significant application of this information has been in the use of anti-EPSIbased monoclonal antibodies (Psl and Psla) for detection of Rs strains from pure cultures and field samples (Alvarez et al., 1993). Assays using this $\mathrm{MAb}$ are specific for Rs strains, highly sensitive (detection limit of $1 \mathrm{ng}$ of purified EPSI by ELISA), and resistant to inhibitors in environmental samples (McGarvey et al., 1998).

A drawback of using EPSI-based $\mathrm{MAb}$ in ELISA is that the cells may be washed away easily during the procedure and the sensitivity tends to be low when viable Rs populations fall below 5 to $6 \log \mathrm{cfu} / \mathrm{mL}$, as shown in this study. Immunostrips created with MAb Psla rely on a different format, trapping the antigen onto a strip. The desirable outcome is a highly sensitive Rs-EPSI detection in drainage water from field samples. Detection of Rs at low levels (1-2 $\log \mathrm{cfu} / \mathrm{mL}$ ) in drainage water in pot studies indicates that the Immunostrips 
Table 2. Survival of Ralstonia solanacearum (Rs) race 4 strain A4515 in soil and potting medium with or without ginger and maintained under alternate days irrigation schedule. Samples were taken directly from the medium after the plants wilted. The shaded region indicates the last day the pathogen was recovered directly from soil or potting medium. Viable cells are reported as $\log \mathrm{cfu}$ per gram $(1 \mathrm{cfu} / \mathrm{g}=28.3495 \mathrm{cfu} / \mathrm{fl} \mathrm{oz})$.

\begin{tabular}{|c|c|c|c|c|c|c|c|c|c|c|}
\hline \multirow{3}{*}{$\begin{array}{l}\text { Growth medium and } \\
\text { inoculation methods }\end{array}$} & \multicolumn{10}{|c|}{ Populations of Ralstonia solanacearum $[\log (\mathrm{cfu} / \mathrm{g}+1)]$} \\
\hline & \multicolumn{10}{|c|}{ Time after inoculation $(\mathrm{d})$} \\
\hline & 81 & 89 & 97 & 105 & 113 & 121 & 129 & 137 & 145 & 153 \\
\hline \multicolumn{11}{|l|}{ Expt. I } \\
\hline \multicolumn{11}{|l|}{ Soil } \\
\hline No ginger ${ }^{\mathrm{z}}$ & $-^{y}$ & - & - & 1.2 & 0.9 & 0.0 & 0.0 & 0.0 & 0.0 & 0.0 \\
\hline Ginger: non-wounded ${ }^{\mathrm{x}}$ & - & - & - & 0.9 & 0.9 & 0.3 & 0.7 & 0.3 & 0.0 & 0.0 \\
\hline Ginger: rhizome wounded ${ }^{w}$ & - & - & - & 1.6 & 0.8 & 0.3 & 0.8 & 0.0 & 0.0 & 0.0 \\
\hline Ginger: stem wounded ${ }^{\mathrm{v}}$ & - & - & - & 1.2 & 0.0 & 0.0 & 0.0 & 0.0 & 0.0 & 0.0 \\
\hline \multicolumn{11}{|l|}{ Potting medium } \\
\hline No ginger & - & - & - & 1.1 & 0.4 & 0.0 & 0.0 & 0.0 & 0.0 & 0.0 \\
\hline Ginger: non-wounded & - & - & - & 0.4 & 1.7 & $1.2^{\mathrm{u}}$ & 0.3 & 0.0 & 0.0 & 0.0 \\
\hline Ginger: rhizome wounded & - & - & - & 1.2 & 0.0 & 0.0 & 0.0 & 0.0 & 0.0 & 0.0 \\
\hline Ginger: stem wounded & - & - & - & 0.7 & 1.5 & 0.3 & 0.0 & 0.0 & 0.0 & 0.0 \\
\hline \multicolumn{11}{|l|}{ Expt. II } \\
\hline \multicolumn{11}{|l|}{ Soil } \\
\hline No ginger & 0.7 & 1.2 & 0.6 & 0.0 & 0.0 & 0.0 & 0.0 & $-^{\mathrm{y}}$ & - & - \\
\hline Ginger: non-wounded & 2.8 & 1.7 & 1.8 & 0.6 & 1.8 & 0.0 & 0.0 & - & - & - \\
\hline Ginger: rhizome wounded & 2.9 & 2.9 & 1.2 & 0.0 & 0.0 & 0.0 & 0.0 & - & - & - \\
\hline Ginger: stem wounded & 2.4 & 2.5 & 1.8 & 0.0 & 0.0 & 0.0 & 0.0 & - & - & - \\
\hline \multicolumn{11}{|l|}{ Potting medium } \\
\hline No ginger & 1.2 & 0.7 & 0.6 & 0.0 & 0.0 & 0.0 & 0.0 & - & - & - \\
\hline Ginger: non-wounded & 2.1 & 0.7 & 0.6 & 0.0 & 0.7 & 0.0 & 0.0 & - & - & - \\
\hline Ginger: rhizome wounded & 0.7 & 0.7 & 0.0 & 0.6 & 1.0 & 0.0 & 0.0 & - & - & - \\
\hline Ginger: stem wounded & 2.3 & 0.8 & 0.0 & 0.0 & 0.0 & 0.0 & 0.0 & - & - & - \\
\hline
\end{tabular}

${ }^{\mathrm{z}} 20 \mathrm{~mL}(0.6763 \mathrm{fl} \mathrm{oz})$ of Rs $(8 \mathrm{log} \mathrm{cfu} / \mathrm{mL})$ were poured into the growth medium (soil/potting medium) with no ginger plants.

y - indicates that no samples were taken for analysis.

$\times 20 \mathrm{~mL}$ of Rs $(8 \mathrm{log} \mathrm{cfu} / \mathrm{mL}$ ) were poured into the growth medium (soil/potting medium) with no wounds to the ginger plants and the rhizome.

w $20 \mathrm{~mL}$ of Rs $(8 \mathrm{log} \mathrm{cfu} / \mathrm{mL}$ ) were poured into the growth medium (soil/potting medium) after wounding the rhizome of the ginger plants by a sterile scalpel.

${ }^{v} 1 \mathrm{~mL}(0.0338 \mathrm{fl} \mathrm{oz})$ of $\mathrm{Rs}(8 \log \mathrm{cfu} / \mathrm{mL})$ were inoculated into the stem of ginger plants with a sterile needle.

"Column means in the same experiment are significantly different at $(P \leq 0.05)$, based on Student-Newman-Keuls test.

may be suitable for testing field samples before and after planting and for regular monitoring of irrigation water sources and runoff from adjacent fields. Immunostrip results were unaffected by the type of growth medium used (soil or potting medium) in this study, indicating that this assay may be used for testing diverse environmental samples.

Detection of RaLstonia SOLANACEARUM IN DRAINAGE WATER BY PCR. PCR-fliC showed positive amplification for all samples from soil with viable $\mathrm{Rs}$ populations $>7$ log cfu/mL (Fig. 4, E and F). The assay detected Rs in $100 \%, 97.1 \%, 96.6 \%$, $81 \%, 61.1 \%, 50 \%$, and $15.9 \%$ of the samples from soil, and in $83.3 \%, 82.6 \%$, $61.5 \%, 38.2 \%, 20 \%, 11.1 \%$, and $14.8 \%$ of the samples from potting medium when populations were between 6 and $7 \log , 5$ and $6 \log , 4$ and $5 \log , 3$ and 4 $\log , 2$ and $3 \log , 1$ and $2 \log$, and 0 and $1 \log \mathrm{cfu} / \mathrm{mL}$, respectively. PCR-fliC performed significantly better on soil samples than those from potting medium. This may be due to the presence of numerous PCR inhibitors in potting medium that lead to inconsistent results, thereby compromising sensitivity, as seen in our studies. The assay detected Rs throughout the experimental period (until $105 \mathrm{~d}$ ). However, numerous samples with high populations were not detected before, during, or after plants wilted. None of the samples in the control pots with no Rs inoculum tested positive.

The detection capability of PCR$f l i C$ was above $80 \%$ when populations of Rs race 4 in drainage water from soil were above $3 \log \mathrm{cfu} / \mathrm{mL}$. An even more sensitive real-time PCR assay detected Rs race 4 at even lower levels of 1 to $2 \log \mathrm{cfu} / \mathrm{mL}$ in ginger rhizomes when samples were enriched in a semiselective medium for 24 h (Thammakijjawat et al., 2006). However, our studies were focused on the testing of numerous drainage water samples from soil and potting medium for the presence of the bacterium, and hence, were different from previous studies.

\section{Conclusions}

Rs survived in field soil in the presence or absence of ginger debris for 120 to $150 \mathrm{~d}$, indicating that the bacterium should survive the fallow period for ginger cultivation, increasing the chances of infection in the new crop. The potting medium used in this experiment reduced the survival of Rs race 4 , and in the absence of a wound, the ginger plants were not infected. Immunostrips had the lowest detection limit among all assays tested and was the most rapid (1 min) and least cumbersome method for detecting the bacterium. Based on the results of this study, Immunostrips have been further selected for environmental monitoring of Rs in ginger fields as well as for evaluating the effects of biofumigants in Rs-infested soils and potting medium. 


\section{Literature cited}

Alvarez, A.M. 2004. Integrated approaches for detection of plant pathogenic bacteria and diagnosis of bacterial diseases. Annu. Rev. Phytopathol. 42:339-366.

Alvarez, A.M., J. Berestecky, J.I. Stiles, S.A. Ferreira, and A.A. Benedict. 1993. Serological and molecular approaches to identification of Pseudomonas solanacearum strains from Heliconia, p. 62-69. In: G.L. Hartman and A.C. Hayward (eds.). Proc. Bacterial Wilt Intl. Conf., Kaohsiung, Taiwan, 28-31 Oct. 1992.

Alvarez, B., M.M. Lopez, and E.G. Biosca. 2008. Survival strategies and pathogenicity of Ralstonia solanacearum phylotype II subjected to prolonged starvation in environmental water microcosms. Microbiology 154:3590-3598.

Araud-Razou, I., J. Vasse, H. Montrozier, C. Etchebar, and A. Trigalet. 1998. Detection and visualization of the major acidic exopolysaccharide of Ralstonia solanacearum and its role in tomato root infection and vascular colonization. Eur. J. Plant Pathol. 104:795-809.

Caruso, P., J.L. Palomo, E. Bertolini, B. Alvarez, M.M. Lopez, and E.G. Biosca. 2005. Seasonal variation of Ralstonia solanacearum biovar 2 populations in a Spanish river: Recovery of stressed cells at low temperatures. Appl. Environ. Microbiol. 71:140-148.

Denny, T.P. and S.-R. Baek. 1991. Genetic evidence that extracellular polysaccharide is a virulence factor of Pseudomonas solanacearum. Mol. Plant Microbe Interact. 4:198-206.

Engelbrecht, M. 1994. Modification of a semi-selective medium for the isolation and quantification of Pseudomonas solanacearum. Austral. Ctr. Intl. Agr. Res. Bacterial Wilt Nwsl. 10:3-5.

European Plant Protection Organization. 2004. Diagnostic protocols for regulated pests: Ralstonia solanacearum. European Plant Protection Organization Bul. 34:155-157.

Fegan, M. and P. Prior. 2005. How complex is the Ralstonia solanacearum species complex? p. 449-461. In: C. Allen, P. Prior, and A.C. Hayward (eds.). APS Press, St. Paul, MN.
Food and Agriculture Organization of the United Nations. 2010. ProdSTAT. 14 Jan. 2010. <http://faostat.fao.org/site/ $567 /$ default.aspx\#ancor $>$.

Hayward, A.C. 1994. The hosts of Pseudomonas solanacearum, p. 9-24. In: A.C. Hayward and G.L. Hartman (eds.). Bacterial wilt: The disease and its causative agent, Pseudomonas solanacearum. CAB International, Wallington, UK.

Hepperly, P., F. Zee, R. Kai, C. Arakawa, M. Meisner, B. Kratky, K. Hamamoto, and D. Sato. 2004. Producing bacterial wilt-free ginger in greenhouse culture. Soil Crop Mgt., Coop. Ext. Serv., College Trop. Agr. Human Resources, Univ. Hawaii at Manoa. 8:1-6.

Horita, M., K. Yano, and K. Tsuchiya. 2004. PCR-based specific detection of Ralstonia solanacearum race 4 strains. J. Gen. Plant Pathol. 70:278-283.

Janse, J.D., H.E.V.D. Beld, J. Elphinstone, S. Simpkins, N.N.A. Tjou-Tam-Sin, and J.V. Vaerenbergh. 2004. Introduction to Europe of Ralstonia solanacearum biovar 2 race 3 in Pelargonium zonale cuttings. J. Plant Pathol. 86:147-155.

Kaneshiro, W.S., M. Burger, B.G. Vine, A.S. deSilva, and A.M. Alvarez. 2008. Characterization of Erwinia chrysanthemi from the bacterial heart rot of pineapple outbreak in Hawaii. Plant Dis. 92:14441450 .

Kelman, A. 1953. The bacterial wilt caused by Pseudomonas solanacearum. North Carolina Agr. Expt. Sta. Tech. Bul. 99:194.

Kubota, R., B.G. Vine, A.M. Alvarez, and D. Jenkins. 2008. Detection of Ralstonia solanacearum by loop-mediated isothermal amplification. Phytopathology 98:1045-1051.

McGarvey, J.A., C.J. Bell, T.P. Denny, and M.A. Schell. 1998. Analysis of extracellular polysaccharide I in culture and in planta using immunological methods: New insights and implications, p. 157-163. In: P. Prior, C. Allen, and J. Elphinstone (eds.)Bacterial wilt disease: Molecular and ecological aspects. Springer-Verlag, Berlin, Germany.

Norman, D. and A.M. Alvarez. 1989. A rapid method for presumptive identification of Xanthomonas campestris pv. die ffenbachiae and other Xanthomonads. Plant Dis. 73:654-658.
Orgambide, G., H. Montrozier, P. Servin, J. Roussel, D. Trigalet-Demery, and A. Trigalet. 1991. High heterogeneity of the exopolysaccharides of Pseudomonas solanacearum strain GMI 1000 and the complete structure of the major polysaccharide. J. Biol. Chem. 266:8312-8321.

Paret, M.L., A.S. deSilva, and A.M. Alvarez. 2008b. Detection of Ralstonia solanacearum with an immunostrip assay; Its specificity and sensitivity. Indian Phytopathol. 61:518-522.

Paret, M.L., A.S. deSilva, R.A. Criley, and A.M. Alvarez. 2008a. Ralstonia solanacearum race 4: Risk assessment for edible ginger and floricultural ginger industries in Hawaii. HortTechnology 18:90-96.

Pradhanang, P.M., J.G. Elphinstone, and R.T.V. Fox. 2000a. Identification of crop and weed hosts of Ralstonia solanacearum biovar 2 in the hills of Nepal. Plant Pathol. 49:403-413.

Pradhanang, P.M., J.G. Elphinstone, and R.T.V. Fox. 2000b. Sensitive detection of Ralstonia solanacearum in soil: A comparison of different detection techniques. Plant Pathol. 49:414-422.

Ravindran, P.N. and K.N. Babu. 2005. Introduction, p. 1-14. In: P.N. Ravindran and K.N. Babu (eds.). Ginger: The genus Zingiber, medicinal and aromatic plants: Industrial profiles. CRC Press, Boca Raton, FL.

Shintaku, M., C. Seeve, and A. Shimabukuro. 2006. PCR assay of the rhizosphere soil of weeds associated with an outbreak of bacterial wilt of ginger in East Hawaii. J. Hawaiian Pacific Agr. 13:9-14.

Schonfeld, J., H. Heuer, J.D.V. Elsas, and K. Smalla. 2003. Specific and sensitive detection of Ralstonia solanacearum in soil on the basis of PCR amplification of $f l i C$ fragments. Appl. Environ. Microbiol. 69:7248-7256.

Thammakijjawat, P., N. Thaveechai, W. Kositratana, J. Chunwongse, R.D. Frederick, and N.W. Schaad. 2006. Detection of Ralstonia solanacearum in ginger rhizomes by real-time PCR. Can. J. Plant Pathol. 28:391-400.

Yu, Q., A.M. Alvarez, P.H. Moore, F. Zee, M.S. Kim, A. deSilva, P.R. Hepperly, and R. Ming. 2003. Molecular diversity of Ralstonia solanacearum isolated from ginger in Hawaii. Phytopathology 93:1124-1130. 